Marquette University

e-Publications@Marquette

Theology Faculty Research and Publications

Theology, Department of

4-1-2009

\title{
Medicine as Friendship with God: Anointing the Sick as a Theological Hermeneutic
}

M. Therese Lysaught

Marquette University

Published version. Journal of the Society of Christian Ethics, Vol. 29, No. 1 (Spring/Summer 2009):

171-192. Permalink. (C) 2009 Georgetown University Press. Used with permission. 


\title{
Medicine as Friendship with God: Anointing the Sick as a Theological Hermeneutic
}

\author{
M. Therese Lysaught
}

A THEOLOGICAL BIOETHICS NEEDS, FIRST, A THEOLOGICAL POLITICS. THE thesis of this essay rests on the claim that the contours of a theological politics are found in the nature of sacramental practices. More specifically, a theological politics of medicine is found in the sacramental practice of anointing of the sick. Anointing provides a radically theological hermeneutic-a theologically robust vision for interpreting medicine that, if enacted, can powerfully make real God's work in the world. Such a vision is embodied in one particular twentieth-century exemplar - the organization called Partners In Health (PIH) and its cofounder, Paul Farmer. Farmer and PIH, I argue, live the theologic and theological politics of medicine embodied in the practice of anointing. What is more, they show-against those who would accuse such an approach of being naively idealistic-that such a theological politics is possible, powerful, and can even change the world.

\begin{abstract}
Many of us have . . . heard a motto such as this: "the homeless poor are every bit deserving of good medical care as the rest of us." The notion of a preferential option for the poor challenges us by reframing the motto: the homeless poor are more deserving of good medical care than the rest of us. Whenever medicine seeks to reserve its finest services for the destitute sick, you can be sure that it is option-for-the-poor medicine.
\end{abstract}

Paul Farmer, Patbologies of Power

Such a claim, I regret to say, was not made by a Christian ethicist. Nor was it made by a theologian, at least a professionally trained theologian. It was in fact made by a physician. When physicians begin to use theological language accurately, pervasively, and unapologetically, Christian ethicists should at minimum sit up and take note. For if it is almost unheard of among theological doctors to find such bold theological language applied in such a straightforward manner to something as dirty-hands-realistic as medical care, it is equally rare among theological doctors. 
Lest I be accused of being too hard on my discipline, I shall claim as a warrant for my assessment Lisa Sowle Cahill's recent book Theological Bioetbics. 1 Here Cahill exhorts Christian ethicists to reclaim robust Christian language for crafting public theological arguments and to employ "expansive" and prophetic theological discourse with regard to medicine. What is more, she calls Christian ethicists to abandon their traditional social location as theorists and become activists. She challenges academic theologians to move beyond theory to praxis, to "mobilize for change," to engage theologically with public bioethics and whomever it takes to alleviate the social conditions that plague most of the developing world, even the developing world within the geographical boundaries of the United States. She seeks to ground her own constructive proposal in a particular political form, participatory democracy. And she holds up as exemplars of such a participatory theological bioethics persons and Christian organizations in the United States and abroad that are working to create alternative practices that embody gospel convictions about issues related to health, healing, and dying.

Of course, I could not concur more heartily with her claims about theological language. And indeed, the greatest strength of her book is the extensive array of exemplars she marshals: the Milwaukee Innercity Congregations for Hope (MICAH); the hospice movement; Joseph Cardinal Bernardin; a Jesuit psychiatrist, Angelo D'Agostino, who heads an orphanage and clinic for children with AIDS in Nairobi, Kenya; the Community of Sant'Egidio, a now-international network of public lay associations committed to prayer, communicating the gospel, and solidarity with the poor; the Catholic Health Association; and many more. Such exemplars stand as important and toooften overlooked sources, models, and perhaps even partners for the work we do as Christian ethicists.

While I side with Cahill on the political nature of a theological bioethics, where I differ with her is on the source of that politics. I have no quarrel with participatory democracy per se. As a participant in the health care issues subcommittee of a local Industrial Areas Foundation (IAF) project in southeastern Wisconsin, I find participatory democracy to have much potential for good. ${ }^{2}$ There certainly may be significant overlap between participatory democracy and the politics of the various Christian organizations Cahill highlightslistening to the voices of all, attention to and maybe even a preferential option for the poor, a vision of the common good, and so on. But fundamentally, participatory democracy is not theological in its source, in its conceptual infrastructure (e.g., its anthropology), in its goal, in any dimension. Therefore, considerable disconnects will most likely arise between the politics of participatory democracy and the politics of Christians, churches, and Christian organizations-differences such as a pragmatism that takes on only those actions with a high likelihood of succeeding, the prioritizing of actions based on benefit to 
members of the organization, a refusal to act solely on principle, and so on. In other words, while churches and Christian organizations might find points of commonality with participatory democracy, might see much good in it, might put the support of their institutions behind its efforts, we must be clear that the politics of participatory democracy is not a theological politics. ${ }^{3}$

A theological bioethics needs, first, a theological politics. Only when first grounded in a theological politics do those doing the work of Christ's body in the world become equipped to discern where they can create alliances with secular politics, where they meet limits in such alliances and why, but whence this politics? My thesis rests on the claim that the contours of a theological politics are found in the nature of sacramental practices. ${ }^{4}$ More specifically, I argue that a theological politics of medicine is found in the sacramental practice of anointing of the sick. ${ }^{5}$ The church has, from the time of its earliest gatherings, attended to ill persons via the communal practice of prayerful anointing. This, theologically, cannot be accidental. Nor can it be incidental to how Christians think about and attend contemporary medicine, especially if we are going to develop a robustly theological bioethics.

A thoroughgoing historical account of anointing is beyond the scope of this essay. Our exploration will proceed no further than the Letter of James. But even from this mere first step I will show that within the practice of anointing we find a radically theological hermeneutic-a theologically robust vision for interpreting medicine that, if enacted, can powerfully make real God's work in the world. For proof of this power we turn to one particular twentieth-century exemplar, one missing from Cahill's account, the organization called Partners In Health (PIH) and its physician cofounder, Paul Farmer. Farmer and PIH, I argue, live nothing less than the theologic of medicine embodied in the practice of anointing. In doing so, they provide one example of what a theological politics of medicine looks like. What is more, they show-against those who would accuse such an approach of being naively idealistic-that such a theological politics is possible, powerful, and can even change the world.

\section{Anointing the Sick: A Practice of Friendship with God}

Cahill is right in identifying language as the pivot on which Christian ethics must turn if it is going to begin to be robustly theological. ${ }^{6}$ After Wittgenstein, however, we know that to speak in such a way requires more than simply words; reclaiming robust theological language requires reclaiming a robustly theological form of life. To speak fluently the language of Christianity with theological hardiness, durability, and stamina in firm, full-bodied, clear, sensible, flexible, and intellectually vigorous sort of way requires frequent travel to-even 
dwelling in-that strange land of Christianity, immersing ourselves in its practices, habits, cultures, rhythms, food ways, and more.

At the center of this form of life, the fount from which our lives flow, take their shape, and to which we must ceaselessly, recursively return for renewal, is sacramental worship. ${ }^{7}$ Sacramental worship comprises a broad and complex array of interconnected practices, the nexus of which is the liturgy of the Eucharist, that sacrament through which Christ is present through Word, bread, and wine, ceaselessly renewing the Body of Christ in all its manifold meanings. But while the Eucharist stands as normative, it has never stood alone. It is informed by and mutually interprets the thicker complex of sacraments as well as the myriad of "sacramental" practices (prayer, works of mercy, giving testimony, and so on) that work in conjunction with the Eucharist to form the Body of Christ and the tapestry of the Christian life. Together sacramental practices provide the wellspring of robust theological language.

Moreover, languages are constituted of far more than words and phrases. As anyone who has learned a foreign language knows, languages carry with them different ways of seeing, understanding, and interpreting. And in seeing the world through a new language, we come to know it differently. Languages and the forms of life to which they are tied are, in other words, intrinsically epistemological. Therefore, to reclaim robust theological language via immersion in the sacramental life of the church is to reclaim robustly theological conceptual tools. It is to reclaim, on one level, a theologic or a theological hermeneutic. ${ }^{8}$

While every sacramental practice is profitable, we might say, for developing a theological hermeneutic for medicine, my analysis here will focus specifically on the sacrament of anointing. From the beginnings of its life together, the church has attended to the sick via anointing, or so the Letter of James attests. ${ }^{9}$ While most of the scholarship on this practice focuses on James 5:12-20 (or some part thereof), I argue that to understand anointing within James' context, it needs to be located within the context of the letter as a whole. The letter is far more complex than can be presented here. For our purposes, I highlight three key features of the letter's rhetorical infrastructure. ${ }^{10}$

The letter's central rhetorical pivot emerges in verse 4:4 where James charges "Do you not know that friendship with the world is enmity with God? Therefore, whoever chooses to be a friend of the world is established as an enemy of God." This fundamental polarity - between "friendship with the world," which is enmity with God and "friendship with God"-is the central principle that organizes and shapes James' message from start to finish. What would it have meant to be "friends of the world"? "Friendship" in the Greco-Roman context was an extraordinarily rich category, carrying much greater weight than the term carries today. "To have friends," Johnson notes, "meant above all to share: to have the same mind, the same outlook, the same view of reality." 11 Those 
familiar with Aristotle, for example, will recall that in the Nichomachean Etbics, the friendship of equals is the highest form of love, and it was the glue that held the polis together. ${ }^{12}$

To be "friends of the world," then, meant to participate in a particular view of reality, of the way things are, that was simultaneously cognitive and political. The "world," for James, does not connote nature or creation, or some neutral space of human activity, or what we might call "the public sphere." Johnson describes it, rather, as a logic, a system of valuing or measurement, that plays itself out in actions and practices. Drawing on the letter as a whole, he characterizes this logic as "envy, rivalry, competition, and murder." 13 As Johnson notes, for James the measure of the world "is defined precisely in terms of the logic of envy. Human existence is a zero-sum game in a universe of limited resources, a closed system. Being and worth are dependent on having; having more means being more, and having less means being less. By this logic, humans are essentially in competition with each other for being and worth, and the surest way to succeed is to eliminate the competition." 14 To be "friends of the world," then, is to share this worldview, to see reality in these terms. It is to believe that the world is a closed system, a universe of limited resources, and it is to live as if this were true: competition, in rivalry, in maximizing one's share of scarce resources, even if my accumulation means that others go without, even if it means, because of this, their death.

To be "friends of God," in contrast, means something altogether and entirely different. To be friends of God is to share God's mindset, God's view of reality, God's "wisdom" (in the language of the letter), and God's corresponding way of being and acting in the world. As is stated almost at the beginning of the letter (in James 1:5, and repeated in 1:17 and 4:6), the essential attribute of God is gift, is giving: "God," James proclaims, "continually gives. . . . God does not restrict giving only to those who make requests, but simply gives 'to all."' 15

To be a friend of God, then, is to know and celebrate the fundamental character of reality, to proclaim this marvelous truth-that God exists, that God is true, and that consequently, the fundamental context of existence is gift-open, abundant, for-the-other not against-the-other. "James' real distinctiveness comes in the breathtaking assertion-grounded in the symbolic world of Torah shared by every form of Judaism including the nascent movement rooted in the "faith of Jesus Christ" - that human existence is not located within a closed system of competition (even for virtue or excellence) but rather within an open system ordered to a God who gives gifts to humanity. This is the theological perspective of faith."16 Faith, in other words, is a claim about reality. The gospel tells a different story about the way things are, and James challenges his community to inhabit and live within that reality, which is the story of God. Thus, "faith by itself, if it has no works, is dead. . . . Show me your faith apart from your works, and I by my works will show you my faith" (2:17-18). 
Friendship with God and friendship with the world, then, are mutually exclusive perspectives. To be a friend of God is to reject the world's way of construing reality and to reject the violence that it necessarily entails. It is to be a person whose essential nature, whose entire character is oriented toward giving, not only to those who ask but simply "to all." Those who choose to side with "the world," however, are not simply and relativistically inhabiting a different story; they are choosing to be "enemies of God." For to see reality differently means to live in reality differently. Indeed, James reserves his most scathing invective not so much for those who are "friends with the world" but for those who are "double-minded," those who want to have it both ways. ${ }^{17}$

This rhetorical framework sets the context for rereading James' more familiar elements. Two in particular are important as we move toward the practice of anointing at the end of the letter. First is James's famous acerbic critique of socioeconomic inequities. Signaled from the very opening of the letter (1:9-12) James particularly castigates those who practice economic favoritism within the assembly (2:1-7), for what could be worse than finding enmity with God practiced within and by the very community that names itself friend of God? The vast disparities between the rich and the poor, and particularly the enculturated behaviors toward both, are a first place where we see what it means in practice to live as "friends with the world" rather than as "friends with God." If God is preeminently the one who gives to all unstintingly, then to amass wealth is to display disbelief in God; to amass wealth when others have little or nothing is to position oneself as God's enemy. Indeed, toward the end of the letter he produces his greatest invective for the rich, raining down woes on their heads for defrauding laborers of their wages. Acquiring such wealth can only occur within the logic of the world, which requires injustice; the essence of this injustice is violence and, indeed, "murder" (4:13-5:6). 18

Thus the lives of those who call themselves friends of God will be characterized by economic sharing, for the view of reality that God gives all to all does not exist apart from embodied actions that make the claim true. ${ }^{19}$ In the community that styles itself as a friend of God, radical socioeconomic inequities are no more. The lowly are "raised up," the rich are "humbled." To say that one believes in God does not to live this belief (does not materially care for the needs of one's brothers and sisters) is to prove claims of faith to be empty.

The framework of friendship with God versus friendship with the world likewise undergirds a second subtheme, namely, the ekklesia as a "community of solidarity." James is often misread as if his injunctions are directed toward individuals and as if the point of his exhortations is to move individuals toward moral perfection. The author of James, however, is a thoroughgoing communitarian. From verse 1:1, James uses plural pronouns and addresses his audience as an ekklesia. ${ }^{20} \mathrm{James}$, in other words, exhorts the community to embody 
a particular identity; he exhorts the community to inhabit and "realize" the truth of the story of God.

Friendship with the world requires us to see ourselves as individuals. The logic of the world, the logic of competition, presumes two diametrically opposed players, locked in a zero-sum game of win-lose. The "other" is a threat to me, a threat of loss, a threat of subjection and oppression, a threat to my very life. To survive requires that I "look out for number one." But a world grounded in a God who gives all to all requires a different anthropology. Fundamental to a theologic of giving is a radically inverted and egalitarian mutuality, for all stand before God, equal in need, equal in giftedness. There is no competition for God's grace and providence. James calls his hearers to see themselves not as individuals in competition but as brothers and sisters in Christ, equal members of a community of solidarity created and sustained by God's grace. Certainly James calls each member of the community "to behavior consonant with the community's" professed identity, but he is most interested in creating "a community of solidarity," one that makes "the choice between a life of envy that logically tends toward the elimination of the other in murder and a life based on gift and mercy expressed in service of the other."21

These three aspects of the Letter of James-his overarching exhortation to friendship with God rather than with the world, lived as a community of solidarity shaped by radical socioeconomic egalitarianism that performs faith and solidarity through act and word-provide part of the context by which to read the practice of anointing the sick. The passage that contains reference to anointing (James 5:12-20) is James's closing exhortation on prayer and positive modes of speech within the community. Anointing, then, is at once a physical action practiced upon sick bodies and simultaneously a mode of speech. Speech for James, of course, is not simply words but is performative, expressed in action (see $1: 22-25 ; 2: 14-26$ ).

In this nexus of touch/speech/prayer singled out in the context of illness we can begin to see the political nature of the practice of anointing. As much as anointing is a practice for the sick person, it is equally an action about and for the community. Notably, the context of James's exhortation to prayer is specific: the context of suffering and sickness. Suffering and sickness can powerfully test faith and can powerfully test the truth of the community's theological construal of reality as the story of a present and provident God. As much as illness threatens our modern social order, for very different reasons James likewise understands sickness to pose "a profound threat to the identity and stability of the community."22

On the one hand, illness threatens the community with social division and alienation. Scriptural passages testify to the social ramifications that attended illness in Jewish culture: ostracism, associations of uncleanness (alienation from their own bodies) and of punishment from God. But this is simply to follow 
the logic of the world, whose natural reflex for survival is to isolate the sick from the healthy, to give them a lower social status out of fear of loss. Health, here, is analogous to a zero-sum game, a commodity that can be taken away by those who lack it.

With illness, the community finds itself faced with a situation akin to that of economic inequities. The language surrounding the practice of anointing, that the Lord will "raise the sick person up," echoes James's opening language of "the lowly brother [being] exalted." While James's use of "raise up" must be heard in its New Testament/gospel context, where it bears equally physical and eschatological meanings (often both at the same time), for James, "raising up" also clearly connotes the overcoming of social distinctions within the community. ${ }^{23}$ The ekklesia is to anoint the sick precisely to counter the social distinctions and alienation introduced into the community by the advent of illness. As Johnson notes, sickness challenges the community of faith to make a choice.

Will it behave like friends of God or like friends of the world? According to the wisdom from below, the proper result of fierce competition is survival of the fittest. The logic of envy is to claim strength at the expense of others. Envy, we have seen, leads to murder. Does someone fall sick? They are weak, leave them by the wayside. Their elimination leaves more resources for me; having to share my attention and resources with them distracts me and weakens me for my own struggle for supremacy and survival. ${ }^{24}$ Importantly, James here (5:14) for the first time, uses the term "ekklesia," for it is the identity of the community as community that sickness threatens. "Will the community rally in support of the weak" asks Johnson, "and show itself to be 'merciful and rich in compassion,' a community based in solidarity, or will it recoil in fear and leave the sick person to progressive alienation?"25

As important, the practice of anointing is for James an action of the ekklesia. ${ }^{26}$ With the advent of sickness, the stakes are raised: sickness requires a specifically communal response. Anointing is an action that takes place within the Christian community as the community of faith; it is an action that embodies the community's claims about its identity as the body of Christ; it is an action that seeks to reinscribe what it knows as truths on the bodies of the sick. The community faces the test of illness and no longer finds the sick person to be a threat; rather they are reminded that the sick person is a gift, is "entirely joy." In the "wound" of illness, inflicted on both the sick person and the community, the Christian and the ekklesia find themselves called to continued openness, openness to the continued possibility of wounding, rather than embodying the logic of the world, which is to close oneself off, to embody the belief that the world is a closed system. Under the aegis of God who gives all to all, the sick in their woundedness are no longer alien threats but rather "those chosen by God to be rich in faith and heirs of the kingdom" (James 2:5). 


\section{Medicine as Friendship with God}

In his book Body Politics: Five Practices before a Watcbing World, John Howard Yoder claims that if Christian sacramental practices were practiced as real activities rather than as spiritualized, interiorized, symbolic simulacra, they "would radically restructure the life of churches." 27 If anointing were to be practiced in the way that James (via Johnson) envisions, the life of the churches would be radically restructured indeed. But so might medicine. As much as Christian practices are about the ekklesia, Yoder also argues that they are for the world. They provide a prototype for "politics" and relationships in the wider world; they proclaim something that the world may not perhaps know, news that "comes across to those who hear it as helpful, saving, and healing"; 28 they provide a paradigm for how life in the world ought to be lived.

Elsewhere I have attempted to narrate what medicine looks like when it chooses to be, in James's sense, friends with the world. Following the logic of envy, rivalry, competition, and murder, modern medicine finds itself in service of the state; allied to violence; caught within a utilitarian, zero-sum economic calculus of scarcity; and ultimately becoming idolatrous, seeing itself as the savior who will bring us to a very different promised land.29

But this is not medicine's only possibility. What might medicine look like when practiced under the aegis of friendship with God? What might medicine shaped by the sacramental logic of anointing be? It will be a practice of medicine structured according to the logic of the world as an open system, ordered to a God who continually gives all to all. Medicine as friendship with God will be lived as a community of solidarity shaped by radical socioeconomic egalitarianism that consequently bears the enmity of the world peaceably with joy and patience as a way of embodying both confidence in God and God's way in the world, and performs faith and solidarity through act and word.

The best way to display such a practice of medicine is to tell a story. Many stories, I think, could be told. For our purposes, I present the story of Partners In Health and its physician cofounder, Paul Farmer. This story is recounted in a remarkable book, titled Mountains beyond Mountains, authored by Tracy Kidder. ${ }^{30}$ Farmer's life and work show what an ecclesially shaped practice of medicine looks like, but it shows most importantly that Christian politics of medicine is not naïvely idealistic-it is possible and powerful.

\section{Paul Farmer and Partners In Healtb}

Paul Farmer is a physician and a professor of both medicine and medical anthropology at Harvard Medical School, the institution from which he concurrently earned in 1990 both his MD and PhD. ${ }^{31}$ Most of the time, Farmer is either on the road or in Haiti, his home for the past twenty years. Haiti has the 
worst health statistics in the Western hemisphere and is the poorest country in the Western hemisphere, with per capita income less than or equal to one U.S. dollar per day.

In the poorest part of this impoverished country, $\mathrm{PIH}$ has built what is essentially a highly effective public health system. Zanmi Lasante (Creole for Partners In Health) includes an ambulatory clinic, a women's clinic, a general hospital, a large Anglican church, a school, a kitchen that prepares meals for about two thousand people per day. In 2005, they logged 1.1 million patient visits (out of a regional population of roughly one million). Patients are not required to pay for treatment. Through its extensive network of accompagneurs (indigenous community health workers), Zanmi Lasante ensures that all of its tuberculosis and HIV patients receive daily or weekly home visits to ensure they are taking their medications. ${ }^{32}$ On these visits, should they discover some other pressing need, like food, housing, transportation, or sanitation, Zanmi Lasante does what it can to address those needs as well.

Since 1994 PIH has expanded its scope to Guatemala, Mexico, Russian prisons, Rwanda, Lesotho, Malawi, and southeast Boston. As they deliver highquality medical care, they have achieved some astounding results. Within their service area in Haiti, they have vaccinated all the children, greatly reduced local malnutrition and infant mortality, and reduced the rate of HIV transmission from mothers to babies to 4 percent, about half the current rate in the United States. They also developed a successful and remarkably efficient approach to the treatment of tuberculosis, which kills more adult Haitians than any other disease and currently kills more than 2 million of the world's poor every year. Globally, they developed a protocol for treating multidrug resistant TB (MDR-TB) with a cure rate never before seen in either a developing context or in the United States (85 percent versus approximately 65 percent). The protocol was adopted by the World Health Organization; PIH then tackled the second seeming insurmountable obstacle to treating MDR-TB among the poor: cost. Within two years, they had negotiated a process that dropped the cost of drugs for MDR-TB more than 90 percent. A disease that had cost $\$ 15,000$ per patient to treat in 1998 cost around $\$ 1,500$ to treat in 2000 ; the cost has continued to fall.

In short, PIH has achieved extraordinary results. But they have done so by practicing what on the surface looks like ordinary medicine-they mostly treat infectious diseases with proven and available remedies and simply provide other forms of primary care. Nonetheless, in many ways their practice of medicine is far from ordinary; it is rooted in a radically different set of assumptions. Their practice of medicine is rooted in the gospels. As Tracy Kidder discovers when he asks how a physician in Haiti finds himself involved in the health of Russian prisoners, "the answer [he finds] is quite simple. Prisoners were part of PIH's special constituency-the Gospels said so; you could look it up in 
Matthew $25 .{ }^{33}$ In other words, PIH strives to intentionally and concretely practice medicine within the framework of the gospels.

Farmer was raised Catholic, but like many who experienced post-Vatican II Catholicism in the United States, he did not find it terribly compelling. As an undergraduate at Duke in the aftermath of Archbishop Romero's assassination, he discovered liberation theology and what he considered a viable form of Christianity. This newfound challenge led him to migrant labor camps and to nuns and other "church ladies" (as he calls them) who amazed him in their championing of Haitian migrant farm workers. This challenge led him to Haiti where the essence of liberation theology came alive for him: "Almost all the peasants he was meeting shared a belief that seemed like a distillation of liberation theology. . . . He felt drawn back to Catholicism now, not by his own belief but in sympathy with theirs, as an act of what he'd call 'solidarity."'34

Church connections have consistently provided an infrastructure for the work of PIH. From their Haitian Anglican partner and colleague, Rev. Fritz Lafontant, who helped Farmer design and build Zanmi Lasante, to the Episcopal Diocese of Upper South Carolina who has supported Lafontant's work, to St. Mary of the Angels and Fr. Jack Roussin, and the many staffers at PIH that Kidder describes as "religious," committed Christians and ecclesial communities have provided the matrix for the work of $\mathrm{PIH} .{ }^{35}$

Consequently, although he identifies his work mainly as that of a cliniciananthropologist, it is difficult not to read Farmer's life as deeply ecclesial. ${ }^{36}$ Farmer certainly does not overlook the many ways in which the institutional church has failed to embody its own mission and has served to exacerbate the suffering of the poor. Yet it is clear how deeply he has been formed by the church, especially the church of the poor in Haiti. In Mountains beyond Mountains, Kidder quietly yet consistently displays how thoroughly Farmer's thinking and life are infused with the gospels. His descriptions of Farmer himself, his interaction with the patients and friends, and his stories of healing evoke nothing less than the gospels. Mountains beyond Mountains itself reads like a gospel narrative; it is the story of a community living the gospel. It has power to transform the reader. It is indeed "good news."

\section{PIH and the Theologic of Anointing}

If this is the story of Paul Farmer and PIH, in what ways does their work capture James' vision? What aspects of their work permit us to describe what they do as practicing a medicine that inhabits the story of God? In what ways does their work embody a Christian politics of medicine that offers an alternative to the politics of "medicine as friends with the world"? Here we find medicine practiced within the story of the Gospel that truly lives as if the world is an open system, ordered to a God who continually gives all to all, shaped by 
a radical socioeconomic egalitarianism, constantly seeking to create a community of pragmatic solidarity that prophetically witnesses against the violence of the world and yet bears the enmity of the world peaceably and patiently.

Farmer construes reality theologically, and he does so from a position that recognizes that in our day and time, there are diametrically opposed ways of understanding the world. In speaking of his own process of coming to realize the real, material meaning of faith (a Jamesian faith embodied in deeds), he notes:

I was taken with the idea that in an ostensibly godless world that worshipped money and power or, more seductively a sense of personal efficacy and advancement, like at Duke and Harvard, there was still a place to look for God, and that was in the suffering of the poor. . . . The fact that any sort of religious faith was so disdained at Harvard and so important to the poor-not just in Haiti but elsewhere too-made me even more convinced that faith must be something good. ${ }^{37}$

Farmer makes James's choice. He makes the decision to live as if God exists, as if God's being is the truth of the universe. He and his communities live, as best they can, God's ways in the world. They take as their mission statement Matthew 25. They think, for example, that it is true. Kidder quotes Farmer: "Inasmuch as you have done it to the least of my brethren, you have done it to me.' He went on paraphrasing. 'When I was hungry, you fed me. When I was thirsty, you gave me something to drink. When I was a stranger you took me in. When I was naked, you gave me clothes. When I was sick, when I was in prison, you visited me. Then it says, Inasmuch as you did it not, you're screwed.' He smiled." 38

Again and again, Farmer and his compatriots embody what it looks like to live as if the truth about reality is that it is an open system ordered perichoretically to a God who continually gives to all. Certainly, Farmer himself embodies this way of constant giving. Not only does he give the gift of his talents, energies, heart, and life to the people of Haiti; he also gives away most of his money. He donates the entirety of his Harvard medical school salary (minus necessary expenses and his mother's mortgage) as well as the stipends, honors, and grants he garners to PIH.

This attitude of trust in God's providence, seeing reality as an open system, also pervades the work of PIH. Kidder recounts how PIH's typical modus operandi is to simply do the right thing, no matter the cost, and figure out how to pay for it later. When Farmer and his colleague Jim Yong Kim began treating MDR-TB in Peru, they "borrowed" the necessary medicines from the pharmacy at Harvard, to the tune of $\$ 92,000$. Eventually, of course, their scheme was discovered, but grace abounds and they found someone who would cover the bill. Elsewhere, when asked about how he again simply appropriated 
the Haiti clinic's first microscope from Harvard he responded: "Redistributive justice. . . . We're just helping them not go to hell." 39

While I am not necessarily advocating wholesale "Robin Hood" approaches to resource redistribution, what intrigues me is Farmer's refusal to be bound by a narrow notion of resource "scarcity." He refuses, for example, to buy the argument that health resources are limited, much less scarce. In his own book, Patbologies of Power: Health, Human Rights, and the New War on the Poor, Farmer claims:

The hypothesis that we lack sufficient means to cure all tuberculosis cases, everywhere and regardless of susceptibility patterns, is not supported by the data. There is plenty of money - even in poor countries. . . . We're told that we live in a time of "shrinking health resources." But is this really so? Look at the profits in the managed-care companies. In the mid-1990s, the Wall Street fournal described these companies as "money machines so awash in cash that they don't know what to do with it all."40

Examples to support his claim could be multiplied. He simply disregards the belief that the system is closed and that medicine ought to be governed by language of competition for scarce resources. From start to finish, his work proclaims simply do what you need in faith, and because the world really is an open system, the resources will follow.

If you really want to get Farmer mad, just use the term "cost effective." Of course, he does not object to being prudent in the use of resources. Rather, he finds the mantra of "cost-effectiveness," especially when employed in rhetoric of international public health, to be not so much a tool but a mask for an essentially utilitarian view of the world that values some people more than others. Treatment of MDR-TB is deemed "cost effective" in a place like New York, he notes, but not in a place like Peru. Moreover, public health policymakers often deem a particular approach to be not cost effective but on the basis of little if any evidence or no substantial trials. "Certainly distributing these developments equitably would be expensive. But how can we glibly use terms like 'cost-effective' when we see how they are perverted in contemporary parlance? You want to help the poor? Then your projects must be 'self-sustaining' or 'costeffective.' You want to erase the poor? Hey, knock yourself out. The sky's the limit!" 41 The mantra of cost effectiveness, in short, serves as but another strategy for simply managing inequality.

As should be obvious by this point, Farmer and PIH practice in an extraordinary way James's socioeconomic critique. Importantly, theirs is not a charity approach to those less fortunate. Central to the success of their work has been an attitude of true, radical egalitarianism among those from PIH and those with whom they live and work. In his own writings Farmer consistently starts from the point of view of the poor. He starts with the stories of the people he has 
known, worked with, and lived among to ground his analysis. He takes their perspective on local and global issues as worth listening to.

It is this valuing of those we might call "the lowly" that indeed has resulted in Zanmi Lasante's phenomenal results with TB treatment. Farmer is very clear on this. Kidder recounts how in the late 1980s a disagreement arose within the Zanmi Lasante staff on why their approach to TB treatment was not more effective. The health professionals (most of whom were Haitian) offered cultural explanations that laid the blame in the minds of patients (e.g., they did not really understand germ theory, vodoo). The Haitian community health workers argued that the impediments to treatment were primarily economic and were particularly related to malnutrition. To resolve this difference of opinion, Farmer designed a study. He divided their TB patients into two groups; both would get standard TB treatment, but one would also receive regular visits from a community health worker and a small monthly cash stipend (\$5) for food, child care, and transportation to the clinic. The cure rates for the two groups were dramatically different: 48 percent in the group that received treatment only and 100 percent in the group that received treatment plus visits plus \$5. The bottom line: Zanmi Lasante adopted the community health workers' approach to treatment, and Farmer's belief in the equality and importance of the perspective of the poor was proven in spades. Since 1988 almost none of their TB patients have died.

Farmer's work-in medicine, in policymaking, in writing-is nothing more than a systematic and consistent effort to "raise up" (in James's words) the poor, to break down barriers of inequality. It is this conviction that all-the sick and the poor, the well and the well-off-are of equal value that drives his scathing critique of economic policies and medical practices that value some lives more than others and that systematically work to (in his words) "erase" the poor. The mantra of cost-effectiveness results in policies that conclude that a patient's survival, her very life, might not be considered "less precious than a fourteen-dollar savings in basic medicine." It requires an anthropology that sees some people, particularly the poor, as "disposable." 42 Too often, the realism of such positions masks a more fundamental belief that the only way to eliminate suffering is to eliminate those who suffer.

It is this conviction that the poor and sick are equal to the well and the welloff that drives his critique of even the well-intentioned, those driven by noble, liberal, or Christian commitments to do mission work and provide charity care. While certainly not wanting to dismiss the good that people do, he reminds us that "attempting to provide a 'basic minimum package' for the poor is something that should be done apologetically, not proudly." 43 The preferential option for the poor, he maintains, compels us not to provide the poor with what little medical care and secondhand castoffs we can (e.g., donated medicines); rather, as noted in the epigraph to this chapter, the notion of the 
preferential option for the poor challenges us to provide the poor with the best medical services. ${ }^{44}$

Crucial to Farmer's analysis of the gross social injustice in the distribution of health resources globally is his critique of the alliance of medicine and nationalism. He questions on a personal level whether being an American is a sufficient identity unto itself, and he reminds us that the notion of resource "scarcity" is a nationalist construct. ${ }^{45}$ Health care resources are indeed scarce in countries whose overall resources are limited, but they are not scarce on a global scale.

In the global era, we often engage in fraudulent analyses of what bounds our "communities" and where they fit in larger social webs. . . . In terms of analysis, those who direct modern commerce are far ahead of us. They understand the artificiality of borders and the gains to be made from differentials in price and supply; they exploit the whole world. Meanwhile, the forces of healing, which deal in the priceless and universal value of health, are trammeled by parochialisms of place and creed. ${ }^{46}$

His rejection of the absurd linkage of national identity and medicine undergirds his most trenchant critique, namely, the relationship between healing and structural violence. Farmer lives and works among some of the poorest peoples of the world. For twenty years he has witnessed the systematic toll taken on the lives of the poor by overt and covert forms of violence wielded by states and multinational economic interests. He carefully demonstrates how the pathological wielding of political and economic power, governed by the zerosum logic of accumulation, envy, rivalry, and competition, can be concretely linked to the devastating scale of human suffering across the globe to tens of thousands of unnecessary deaths every day. More specifically, he shows how this pathology translates directly into biological pathology, namely, the massive health crises of the third world. These pathologies create what he calls "structured risk," highly predictable patterns of violence, human rights abuses, social and economic deprivation, and illness far from the random or haphazard crises they are generally purported to be. For Farmer, this pathological wielding of power, and the systemic violence that attends it-in other words, our global status quo that embodies friendship with the world-constitutes an essentially undeclared war on the poor.

In the end, Farmer argues that the answer to this state of affairs is "pragmatic solidarity." He proposes that the symbolic core of the embodiment of pragmatic solidarity ought to be health and healing. Much like James, who calls his own hearers to become a community of solidarity, Farmer challenges us in the United States to enter into community with those beyond our borders, to see the destitute sick worldwide not as unfortunate individuals but as "among us," as members of our community with whom we must be in pragmatic solidarity. 
Such a community of solidarity embodies a life based on gift and mercy expressed in the service of the other. Informed by Farmer's vision of the option for the poor, where the poor are understood to be equally valued members of the community, to be listened to and not simply to be the objects of Western charity, the community of solidarity will be genuinely radically egalitarian.

And it may be a community that suffers and will be tested because of its attempts to live the story of God. As Farmer declares:

How about if I say, I have fought for my whole life a long defeat. How about that? How about if I said, That's all it adds up to is defeat? . . . I have fought the long defeat and brought other people on to fight the long defeat, and I'm not going to stop because we keep losing. Now I actually think sometimes we may win. I don't dislike victory. . . . What we're really trying to do is to make common cause with the losers. . . . We want to be on the winning team, but at the risk of turning our backs on the losers, no, it's not worth it. So you fight the long defeat. ${ }^{47}$

PIH keeps trying to do the right thing, success or no, effectiveness or no. And they do so peaceably, for the only way to counter the structural violence in which the poor are enmeshed is to offer a peaceable space of healing and solidarity that can act as an antidote to the insidious effects of oppression.

\section{Toward a Theological Bioethics}

What might Farmer make of my claim that he and PIH embody a theological hermeneutic of friendship with God rooted in the sacramental practice of anointing of the sick? While he certainly might regard it with interest, I do not doubt that it would come as a surprise. For PIH is not explicitly a religious organization. Robust religious convictions and language notwithstanding, PIH is not a ministry of the church; it is not an ecclesial community; it is not in any obvious way sustained through Christian sacramental practices.

Nonetheless, I would suggest that the connection between the theological hermeneutic of anointing and Farmer's politics of medicine might be sustained. Admittedly, I have offered only the first step in the development of a hermeneutic or politics rooted in anointing. A thoroughgoing account would trace the development of the practice backward into the gospels and forward through the early church and Middle Ages; it would chart its devolution into extreme unction and its twentieth-century reform and renewal as it has sprung forth across denominational lines; it would trace how the churches commitment to caring for the sick embodied in anointing was carried in the life of the church through a myriad of ways, including monastic care for the sick, the healing cults of the saints, the many orders of religious women devoted to care for the sick, 
and the development of Catholic and other religious hospitals systems; and it would attend to the ritual and sacramental theology of the revised rite, at least in the Roman Catholic church, as well as to its renewed practice in the lives of ecclesial communities.

Such a display would, I believe, reinforce again and again the fundamental politics of the practice found in James. And as the vision and practice embodied in the early Christian communities is carried forward in the life of the church through the practice of the sacrament and the healing ministries of the church, we could sketch the ways that liberation theology and the praxis of the many people supporting Farmer and PIH over their journey imparted to them this political hermeneutic. Moreover, although Kidder does not mention the worship life of the community at Zanmi Lasante, Reverend Lafontant's church is clearly the cornerstone of the complex, and as anyone who has been to Haiti or to most developing countries knows, worship in such an environment is a time-filled, embodied, communal affair.

Thus a case for a causal connection between anointing and $\mathrm{PIH}$ might well be made, but that is beyond my purpose. Here I simply wished to hold up two practices-the earliest church's practice of caring for the sick and a contemporary physician's practice of caring for the sick-and note their remarkable similiarities. If one were to script a Christian politics of medicine, one would be hard pressed to find a better exemplar. Over and against contemporary medicine with its assumptions that map, troublingly, onto James' characterization of friendship with the world, PIH utilizes a different hermeneutic vis á vis questions of medicine and health care delivery; a hermeneutic richly and robustly informed by theological language, language derived from Scripture and worship; a hermeneutic that embodies the theologic of the practice of anointing. And PIH demonstrates that such a practice of medicine is not only possible; it is extraordinarily effective and transformative not only of the poorest of the poor but of the very discipline of medicine. But of course, grace always is.

Here, then, we have the theology and praxis of a robustly theological bioethics, a praxis that embodies the politics of the body of Christ rather than participating in the politics of the world. The ability of PIH to embody such a theological politics suggests that this hermeneutic that emerges from the practice of anointing may well be applied to other aspects of medicine, and that there the outcome might be equally powerful and transformative. The story of Dame Cicely Saunders, for example, similarly embodies "medicine as friendship with God" with regard to the terminally ill, and the story of Jean Vanier and L'Arche shows what it looks like in the care of persons with disabilities. How might such a hermeneutic help us to rethink other areas in medicine?

As we begin to reimagine what medicine might look like if practiced as friendship with God, it is not only Christian theologians and ethicists who are called to self-examination. This theological hermeneutic rooted in anointing 
issues an important challenge to Christian health care institutions: Are they (are we) the double-minded? Too often it seems that Christian health care and Christian ethicists focus their energies on trying to create a kinder and gentler Leviathan. Do we merely soften the edges of a medicine that has befriended the world by adding to it dashes of faith? Do we spend most of our time debating about how to manage what Farmer calls "the quandaries of the fortunate," practices such as physician-assisted suicide or cloning or stem cell research or genetic testing? Too often we find ourselves caught up in the language of "cost effectiveness," "stewarding scarce resources," and utilitarian reasoning, subordinating "mission" to "margin." Too often we proceed as if national boundaries were really meaningful in a transnational church.

As the Eucharist makes the church, so it is that only a center in sacramental worship can make a theologically robust Christian ethic-in both theory and practice. A renewed appreciation of the practice of anointing of the sick provides a starting point for theological ethicists to begin to build a thickly theological hermeneutic for engaging medicine in the twenty-first century. But equally, it provides those same theologians and other Christians a way forward in living James' vision, in embodying the cruciform gospel in pragmatic solidarity with the poor. As we turn anew to the sacrament of anointing, it can begin the work it was originally instituted to do-to heal, renew, and sustain the Church as Church, so it can continue to live its mission in the world, embodying its identity as the Body of the Christ known in and through the gospels.

\section{Notes}

Epigraph. Paul Farmer, Patbologies of Power: Health, Human Rights, and the New War on the Poor (Berkeley: University of California Press, 2003), 155, emphasis in original.

1. Lisa Sowle Cahill, Theological Bioetbics: Participation, fustice, Change (Washington, D.C.: Georgetown University Press, 2005).

2. Southeastern Wisconsin Common Ground, an IAF affiliate, was launched in April 2008 after two years of grassroots background work. For more information on this project, see www.commongroundwi.org/.

3. It is worth noting that most of the founding member organizations of the Southeastern Wisconsin Common Ground are local churches.

4. This is by no means an original claim. This essay is deeply informed by the work of John Howard Yoder, especially his book Body Politics: Five Practices of the Cbristian Community before the Watcbing World (Herald Press, 1992). Beyond Yoder, see the many works of William T. Cavanaugh, including his Theopolitical Imagination (Edinburgh: T\&T Clark 2003) as well as Bernd Wannenwetsch's Political Worship: Ethics for Cbristian Citizens (New York: Oxford, 2004).

5. This essay is part of a larger project that seeks to develop a theological hermeneutics for medicine rooted in the ancient Christian practice of anointing of the sick. Preliminary work for this project can be found in M. Therese Lysaught, "Patient Suffering and the Anoint- 
ing of the Sick," On Moral Medicine: Theological Perspectives in Medical Etbics, 2nd ed., eds. Stephen E. Lammers and Allen Verhey, 356-64 (Grand Rapids, Mich.: Eerdmans, 1998); and Lysaught, "Suffering, Ethics, and the Body of Christ: Anointing as a Strategic Alternative Practice," Cbristian Bioetbics 2 (1996): 172-201. My recent work in this area is indebted to the generosity of the Louisville Institute and their Christian Faith and Life grant program.

6. "Robust" is Cahill's term, one that I find extraordinarily well chosen. Consider the definition of robust (adj): (1) strong, healthy, and hardy in constitution; (2) built, constructed, or designed to be sturdy, durable, or hard-wearing; (3) involving or requiring great physical strength and stamina; (4) rich, strong-tasting, and full-bodied; (5) characterized by firmness and determination and a refusal to make concessions; (6) showing clear thought and common sense; (7) rough and direct or crude (rare); (8) able to recover from unexpected conditions during operation. Encarta World English Dictionary, 1999 Microsoft Corporation. Similarly, see the Oxford English Dictionary, which adds the variant "vigorous in mind."

7. The centrality of the liturgy for the life of the Church and the lives of Christians was clearly articulated at the Second Vatican Council, (1963), The Constitution on the Sacred Liturgy (Sacrosanctum concilium) in A. Flannery (ed.), Vatican Council II: The Conciliar and Post Conciliar Documents, study ed., (Northport, N.Y.: Costello Publishing Co., 1986), no. 10.

8. Gavin D'Costa, in his important essay "The Anatomy of a Love Affair, or, How to Do Theology on Your Knees," argues persuasively for the epistemological necessity of worship for the intellectual discipline of theology as well as for the practice of the Christian life; New Blackfriars 79, no. 925 (March 1998): 116-35.

9. My reading of James derives largely from Luke Timothy Johnson's splendid commentary on and translation of the letter: The Letter of James: $A$ New Translation with Introduction and Commentary (Anchor Bible, vol. 37A), (New York: Anchor Bible/Random House, 1995). Unlike many commentators, Johnson rejects the long-traditional reading that the letter is simply a loose compilation of disconnected aphorisms and moral exhortation, and argues that James possesses not only internal coherence and argument but also a compelling vision of the contours of the Christian life. In addition, Johnson concurs with other recent commentators that over against a long standing history of understanding James as one of the latest New Testament writings, it is likely one of the earliest.

10. For a more complete account, see my essay "Vulnerability within the Body of Christ: Anointing of the Sick and Theological Anthropology," in Health and Human Flourishing: Religion, Medicine, and Moral Antbropology, ed. Carol R. Taylor and Roberto Dell'Oro (Washington, D.C.: Georgetown University Press, 2006), 159-84.

11. Johnson, Letter of James, 85.

12. Friendship, from the gospels forward, is a key feature of a theological politics.

13. Johnson, Letter of fames, 288.

14. Ibid., 85.

15. Ibid., 86.

16. Ibid., 183-84.

17. James's invective against the double-minded seems particularly directed at the rich and the powerful-those who want to maintain the benefits they derive from "the world," who largely espouse the world's values (control, making money, individual prestige, and power) but are members of James' community. Stephan Alker ('Interextuality in Mark 4 and Isaiah" paper presented at Marquette University, November 15, 2007) has argued that a similar sort of polarity is present within Mark's gospel and in Isaiah, but that this polarity is not to be understood as a dualism between the "church" (or Israel) and "the world" in the 
way it is typically framed in contemporary theological discourse In other words, it is not a position designed to denigrate those in "the world" as such Rather, it is an internal claim, calling those within the community to account Thus it is the "double-minded" who emerge as the greatest villains of the letter

18 James certainly is not speaking of wealth metaphorically

19 James's first elaboration of the infamous disjunction between faith and works concerns caring for the needy "What use is it, my brothers, if someone says he has fath but does not have deeds? Is the fatth able to save him' If a brother or sister is going naked and lacking darly food, and if one of you should say to them, 'Go in peace' Be warmed and filled,' but does not give to them what is necessary for the body, what is the use?" (James 2 14-15)

20 Johnson, Letter of James, 81

21 Ib1d, 82

22 Ibid, 342

23 For an intertextual reading of the terms "save" and "raise up" in James 5, see my essay "Rıse Up and Walk" Healed Bodies and the Performance of the Resurrection in Mark's Gospel," Fournal of the Christzan Theological Researcb Fellowship (in press) Originally presented at the Amencan Academy of Religion, Annual Meeting, 2007

24 Johnson, Letter of Fames, 342

25 Ibid, 343

26 When James turns his attention to the situation of the sick, the community becomes the agent Throughout this section he is addressing the community is anyone among you sick?

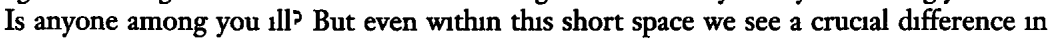
actions "Is anyone among you suffering" Let that person pray Is anyone feeling good" Let that person sing " In verse 13 , individuals are exhorted to act within the community But in the event of sickness, the dynamic shifts "Is anyone among you sick' Let that person call the elders of the assembly, and let them, after anointung him with oil in the name of the Lord, pray over the person " Interestngly, "we notace first that James empowers the sick themselves with respect to the community When they are ill, they are to call the elders of the community James's language has a formal quality they are to summon the elders [5 14] James then enjoins the elders to pray over and anoint the sick person in the name of the Lord In the elders, the ekklesia is to respond to the weak member and overcome the alienation and inerta with which sickness threatens the life of the group" Johnson, Letter of James, 342-43)

27 Yoder, Body Politics, 7

28 Ibid, 44

29 See, for example, $M$ Therese Lysaught, "And Power Corrupts Theology and the Disciplinary Matrix of Bioethics," in Handbook of Broetbics and Religzon, ed David Gunn, 93-123 (Oxford Oxford University Press, 2006), and Lysaught, "Love Your Enemies The Life Sciences in the Ecclesially Based University," in Conficting Allegiances The CburchBased Untversity in a Laberal Democrattc Soctety, ed Michael Budde and John Wesley Wright, 109-27 (Grand Rapıds, Mich Brazos Press, 2004)

30 Tracy Kidder, Mountains beyond Mountains The Quest of Paul Farmer, the Man Who Would Cure the World (New York Random House, 2003)

31 Farmer's story is not simply the story of an individual His life can only be recounted by simultaneously interweaving his story with that of the not-for-profit organization Partners In Health (PIH), which he cofounded in 1987 with his friends and partners Ophelia Dahl, Jım Yong Kım, and Tom White 
32. The PIH website claims that in 2005 their accompagneurs logged over 1.4 million visits to patient homes-this in addition to the patients seen in their clinic facilities. See www.pih.org/where/Haiti/Haiti-timeline.html.

33. Kidder, Mountains beyond Mountains, 221.

34. Ibid., 78.

35. While in medical school, Farmer lived in a room under the eaves of the rectory at St. Mary of the Angels parish in Boston, a largely African American parish located in Roxbury, one of Boston's economically depressed neighborhoods. The pastor was Fr. Jack Roussin, who in his life and particularly through death, plays a pivotal role in PIHs move from Haiti to the global scene.

36. One need only recall the Lenten cycle of lectionary readings, with their prophetic economic critique, or the voice of James, to hear in Farmer's paradigm shift a fundamentally theological move. He devotes an entire chapter of his own book, Patbologies of Power, to a description of liberation theology and a discussion of its implications for medicine and health policies, and his language throughout all these works is deeply infused with scriptural references and the spirit of the gospel. In Patbologies, for example, he refers to his narration of the stories of individual suffering as "bearing witness" and to his own work as "prophetic witness," and the title of the book certainly evokes the biblical notion of "principalities and powers." He calls his readers to "a posture of penitence and indignation" linked to pragmatic intervention. And he explicitly identifies his work as a work of theodicy. In his theodicy, suffering is not God's fault-it can be traced to human agencyand his task is to make visible these "explanations" of suffering.

37. Kidder, Mountains beyond Mountains, 85.

38. Ibid., 185, emphasis in original.

39. Ibid., 149.

40. Farmer, Patbologies of Power, 172-73.

41. Kidder, Mountains beyond Mountains, 177.

42. Farmer, Pathologies of Power, 175, 169.

43. Ibid., 177.

44. Ibid., 155.

45. Kidder, Mountains beyond Mountains, 82.

46. Farmer, Pathologies of Power, 172.

47. Farmer, quoted in Kidder, Mountains beyond Mountains, 288, emphasis in original. 